Original Scientific paper

Received 11.1.2018.

Approved 24.5.2018.

\title{
CORRUPTION AS A JEOPARDIZING FACTOR OF HEALTH CARE SYSTEM DEVELOPMENT IN THE REPUBLIC OF SERBIA***
}

The main problem of the research in this paper is the corruption in the health care system of Republic of Serbia, with a focus on criminal offenses against official duty, viz. criminal offenses under Article 367 and 368 of the Criminal Code of Republic of Serbia: bribery committed by health workers. The subject of the paper is the research of the corruption as a jeopardizing factor for the development of the health care system. The objective of the paper is to acquire adequate, scientific and social knowledge of various forms of corruption and mechanisms that the state authorities should use in the combat against this type of threat to society as a whole. Health care refers to the organized and comprehensive activity of the society whose aim is to achieve the highest level of preserving the health of citizens and families. Therefore, the main hypothesis in this study is that a higher level of corruption in the health sector means a lower level of health care in society. In other words: the poorer the quality of the health care, the slower the economic development of society will be. What is particularly emphasized in the paper is that the combat against corruption in the health care system is one of the conditions for the EU Accession. The data in this paper have been obtained through content analysis of the documents by associations of patients, judicial bodies and other organizations related to corruption in the health care system of the Republic of Serbia.

Keywords: Corruption, Health care system, Economic development, receiving Bribes, giving Bribes, a Patient.

Head of legal and general office of Institute for Orthopedic Surgery diseases "Banjica", dusan.rajakovic@gmail.com

** Faculty of Law Megatrend University, toljapc@yahoo.com

*** This paper was presented at the $21^{\text {st }}$ International Scientific Conference on Economic and Social Development, 18-19. May 2017, Megatrend University, Belgrade 


\section{Introduction}

Corruption as a negative social reality has been present throughout the history of human society. It has always been the subject of study from a sociological, philosophical and legal aspect. From Ancient Greece to the present day, many thinkers have considered corruption as the deterioration of governments and social values, as well as the decline of the moral values.

Contemporary definitions of corruption can be classified as ${ }^{1}$ :

- Administrative definition of corruption - corruption is a deviate behavior of an individual in relation to the formal role;

- Economic definition of corruption - corruption is getting maximum profit by violating laws and moral;

- Public - Interest definition of corruption - using public utilities for personal interests;

- From a criminological aspect, an acceptable definition might be: corruption is a criminal behavior in which the assigned authority is misused for the purpose of personal gain ${ }^{2}$.

Particular weight in deviant behavior of an individual, from a moral point of view, is the corruption in the health care sector. Primarily because it additionally worsens the condition of patients and their families.

It is important to mention the aspirations of the Republic of Serbia for the EU membership, primarily for economic development that would be the basis for the development of the entire society. One of the most important conditions that Serbia needs to fulfill is to reduce corruption in all social systems, particularly in health care system. Undeveloped or underdeveloped countries are a fertile ground for the development of corrupt activities.

Therefore, it is very important to create social opportunities and intergovernmental relations that will contribute to the fulfillment of the conditions for the EU accession.

\section{Health care system}

Health care in the Republic of Serbia is regulated by the Law on Health protection $^{3}$. Health care refers to the organized and comprehensive action of the society whose aim is to achieve the highest level of health preservation of citizens and families, and includes the implementation of measures to preserve

Government of Republic of Serbia, Anti-Corruption Council, the official website.

Ignjatovic, Dj. (2011): Criminology, Dosije studio, Belgrade, pg. 112.

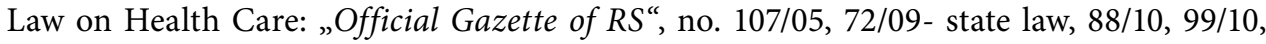
57/11,119/12, 45/13-state law, 93/14, 96/15 and 106/15. 
and improve citizens' health, control and early detection of diseases, injuries and other health disorders, along with timely and efficient treatment and rehabilitation.

Any citizen of the Republic of Serbia or any other person with domicile or residence status in the territory of the Republic of Serbia has the right to health care. Ensuring health care for the population is based on the principles of accessibility, fairness, comprehensiveness, continuity, and permanent improvement of health care quality and efficiency. Health care of the population is carried out at the national level, level of the autonomous region, municipality or city level, or at the level of an employer and an individual.

Health care institution can be established by the Republic, the autonomous region, the local government, natural or legal person, under the conditions stipulated by the Law. It can be established using public or private property resources, unless otherwise specified (institutions that perform emergency medical care, preservation and transplantation of organs and parts of the human body, institutes of blood transfusion and public health, etc. are established exclusively by the state).

Private practice may be established by an unemployed health care worker with professional practice exam and a health worker, the beneficiary of old-age pension. Private practice, as a form of health care service, can be set up as a health office, clinic, laboratory, pharmacy and infirmary. A founder of a private practice has the status of an entrepreneur and self-employed, and is allowed to set up only one form of private practice. Health workers may establish a private practice if they meet the conditions prescribed by the Law on Health care, such as general health ability, university degree or appropriate professional medical school, have passed the professional practice exam, are registered by the competent Chamber of Commerce, or have the appropriate license to operate. Private practice can also be set up and health care activities performed if the conditions in terms of personnel, equipment, facilities and the availability of appropriate types and quantities of medicines and medical devices are met.

Health industry in the Republic of Serbia is carried out at the primary, secondary and tertiary health care level. Management bodies of the health institutions are the Director, Steering and Supervisory Board.

\section{Types of corruption in health care system}

The most common types of corruption in the health care system in Serbia are:

- demanding money from the patients for the provision of health services, shortening the time on the waiting list for medical examination, diagnostic test and surgery;

- $\quad$ refusing to provide medical services without justifiable medical reasons; 
- referring patients from state to private health institutions (the reason is usually inability of state institutions to provide adequate service to the patient);

- prescribing drugs of pharmaceutical companies from which doctors receive a fee or other material benefit;

- wrong doing in drug market and medical equipment market.

a) Receiving bribes

The doctors must not use their medical profession or position in order to acquire illegal material gain or benefit for themselves or for someone else ${ }^{4}$.

Receiving bribes is the most common form of corruption in the health care system in Serbia. Bribe is primarily given in cash, gifts or other benefits. It is a case of criminal offense under Article 367. Paragraph 1 "An official who directly or indirectly solicits or accepts a gift or other benefit, or a promise of a gift or other benefit for himself or another person to perform an official act within his competence, or in relation to his/her official powers that should not be performed, or not to perform an official act that should be performed, shall be punished by imprisonment of two to twelve years ${ }^{5}$."

Receiving bribes is usually done through unlawful mediation. Health workers who make such offenses usually do not personally ask for money, but do the act through another physician or medical personnel.

The best example for this is the final judgment of the High Court in which Z.G., employed as the official orthopedic specialist of the Institute for Orthopedic Surgery "Banjica", was sentenced to a term of imprisonment of 2 (two) years for accepting bribes. Z.G. directly demanded money for himself from the aggrieved party K.M. to perform an official act which he was obliged to do within his official mandate ${ }^{6}$. The mere fact that a long period of time passes from the moment of the offense commitment to the pronouncement of the final judgment (often the procedure is statute-barred) is an aggravating factor in the suppression of such a criminal work.

\section{b) Giving bribes}

The biggest problem in solving the problem of corruption in the health care system is caused by the patients themselves. A sick person sometimes does not choose a method and means to solve their health problems. The closest relatives also offer money to ensure successful treatment of their sick family members.

$4 \quad$ Code of Medical Ethics of the Medical Association of Serbia, “Official Gazette RS”, nos. 104/2016, article 18.

5 Criminal code, "Official Gazette of RS", nos. 85/2005, 88/2005 - emendation, 107/2005 emendation. 72/2009, 111/2009, 121/2012, 104/2013, 108/2014.

6 Republic of Serbia, High Court in Belgrade, K.no.760/12. 
In that way, they enter into the cycle of corruption in health care, which authoritatively makes them a criminal offender.

Whoever makes or offers a gift or other benefits to an official or other within his official competence or in relation to his/her official powers, perform an official act that he is obliged to perform, or not to perform an official act that he may not perform, or who acts as intermediary in such bribing of an official, shall be punished by imprisonment up to three years ${ }^{7}$.

Analyzing the research results, it can be concluded that a bribe-giver lacks awareness that by giving a gift or doing a favor, they actually make a serious crime.

c) Refusal to provide health services

This is usually the first step that health workers take as a way to influence a patient to agree to some form of corruption, which is often an unavoidable situation for a patient. Refusal to provide medical services can have various forms, and one of them is putting a patient on a waiting list for a long period without any objective reasons, after which a patient decides to give money in order to be examined or medically treated in other way as soon as possible. Also, doctors very often refuse to provide medical services at the workplace in the state health care institutions, making a patient who is concerned about their health to accept a treatment in a private institution. In this case, there are elements of the offense of denying medical assistance, as well as malpractice.

\section{d) Referring patients from state to private institution}

This is one of the most prevalent forms of corruption in the health care system of Serbia and very difficult to prove in criminal proceedings. It can be undoubtedly concluded that in this way health workers have built a parallel system of health care. It is a "well-coordinated" system in which a doctor refers the patient to a private health institution run by his colleagues or doctors, who give him money for the "referral". It happens very often that the referred clinic is where the doctor works himself or even owns it. It is a fact that state health institutions are not always able to provide all kinds of services and health care. However, the same offense happens even when state health institutions have the capacity to provide the necessary service. In addition, it happens that physicians refuse to accept the results of laboratory analysis of some private laboratories, and therefore send patients to other laboratories from which they obviously receive money or other material benefits. For the patients, or the "victims" of this form of corruption, doctors have in advance prepared business cards of private health institutions they "cooperate" with. For this type of corruption, the major problem of argumentation in criminal proceedings is patients' consent to

Criminal Code, “Official Gazette of RS”, nos. 85/2005, 88/2005 - emendation, 107/2005 emendation. 72/2009, 111/2009, 121/2012, 104/2013, 108/2014. 
the "recommendation", when patients want to cure themselves or their family members in the first place, thus becoming part of a parallel health system.

\section{e) Link between health care workers and the pharmaceutical industry}

Actions of this type of corruption involve advertising, promotion and recommendations made by a doctor for a medication which is a product of certain pharmaceutical companies, while the doctor receive money or other benefits from that pharmaceutical company. The doctors who insist that patients use certain medications whether they are on the positive list or not make this type of corruption more difficult in particular. In addition, pharmaceutical companies pay conference fees for the doctors' participation in scientific conferences.

This form of corruption, i.e. the link between health care workers and the pharmaceutical industry, is recognized in the National Anti-Corruption Strategy ${ }^{8}$.

\section{f) Wrongdoing in drug market and medical equipment market}

Additional difficulties are made by pharmaceutical companies and manufacturers and retailers of medical equipment. With the purpose of making a profit and achieving commercial interest, they commit a series of "frauds". Perhaps the most prominent type is offering outdated medical equipment at a cost of modern equipment, with the aim of "emptying the warehouse" and reducing potential costs and losses that could be caused by the impossibility of placing products on the market. Very often, the failure to disclose the actual quality of drugs and their adverse effects makes the problem even more severe.

\section{Safeguards against corruption in health care system}

It is clear that there is a shortfall in the system. Cases of corruption in the health sector are numerous and daily, while the number of court judgments that condemn health workers is negligible. Therefore, what goes in favor of misuse is the lack of clear procedures and a list of standard services; criteria and procedures for performing additional work, whose cash income does not return to the budget, but is distributed to institutions and their employees (the existence of the so-called institution's own revenues); imprecisely regulated relation of the pharmaceutical industry in terms of medical practice and training of health care employees; loosely regulated legal conditions that health care staff and associates in state institutions need to fulfill in order to provide health services in private institutions, etc ${ }^{9}$.

8 National Anti-Corruption Strategy for period 2013-2018, “Official Gazette of RS”, nos. 57/2013. 3.7. Health a) Description of situation.

9 National Anti-Corruption Strategy for period 2013-2018, “Official Gazette of RS”, nos. 57/2013. 3.7. Health a) Description of situation. 
The issue of corruption needs to be observed from a security standpoint as well. Given that there is no institutional mechanism for its effective suppression, this phenomenon requires a coordinated and determined response of all security structures in society ${ }^{10}$. Additionally, an important mechanism for the combat against corruption in the health care system is the professional work of judicial bodies. However, that is not supported in practice, where justice can be seen as "disorganized box" that excludes the idea of an anti-corruption strategy that can be applied within its walls ${ }^{11}$. Recognition of the health sector as the primary segment of society will contribute to the development of society as a whole, as well as better regulation of the relations of state bodies. Court proceedings must be resolved urgently in order to emphasize the state readiness to vigorously and decisively combat the problem of corruption in the society, particularly in health care system as its most sensitive part. The experiences of developed countries can be a good example to follow.

\section{Evaluation of research results}

Research on corruption in health care was conducted by the Center for Free Elections and Democracy in 2010 on the territory of the Republic of Serbia ${ }^{12}$. The results that have been reached allow us to conclude that the existence of corruption is at the level of "rumours", and that there are no significant direct knowledge and findings of the respondents. Also, a number of respondents who might have been involved in corrupt activities, do not literally consider corruption to be a criminal offense, but rather a symbolic gesture, particularly underlining that they were not under anyone's, either direct or indirect, pressure. It is interesting that there are no significant differences in responses depending on the age, sex, level of education and material status of respondents. Majority of the respondents think that reporting corrupt activities to the competent authorities is the best way to combat corruption and contribute to its reduction while patients themselves have to report any type of corruption. In addition to customs officers, doctors make the profession which is generally believed to be the most corrupt. Health workers on the other side think that corruption in the health care system is not widespread, and that reasons why individuals resort to corrupt activities should be sought in poor working conditions, primarily in low-income, insufficient to meet basic human needs.

\footnotetext{
$10 \quad$ Danilovic, N. (2013): Contemporary security systems, Megatrend, Belgrade, pg. 51.

11 Petrus C. van Duyne, Elena Stocco, Jelena Dimitrijević (2012): From black box to a transparent public policy, Victimology Society of Serbia, Belgrade.

12 Center for Free Election and Democracy (2010): Corruption in Health care.
} 
Chart $1^{13}$

\section{Have you or a member of your family ever been in a situation to} bribe an employee of the health care system in the last five years?

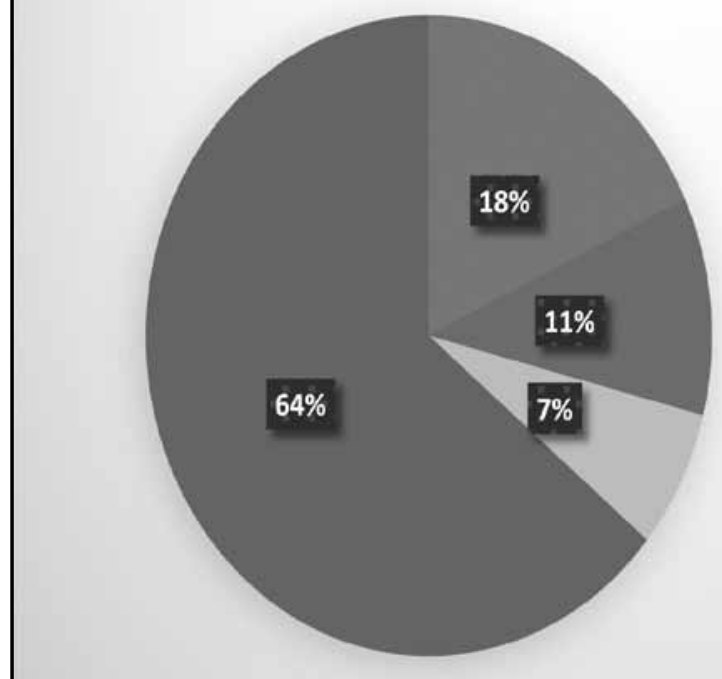

A member of my family has given a bribe

Yes, I have, for a family member

Yes, I have, for mysalf

No, there hes not been such a situation

Chart $2^{14}$

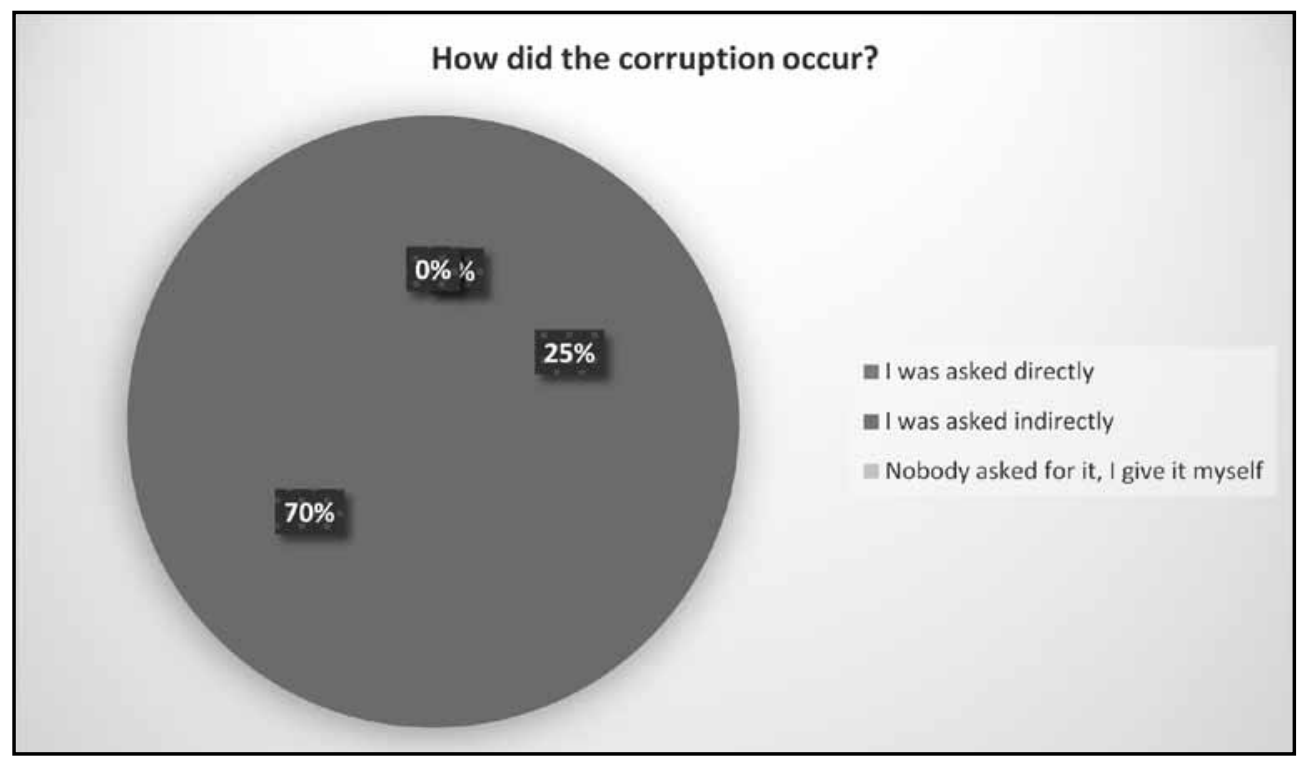

13 Center for Free Election and Democracy (2010): Corruption in Health care.

14 Center for Free Election and Democracy (2010): Corruption in Health care. 
Chart $3^{15}$

\section{Who to a greater extent promotes the existence of corruption in health care system?}

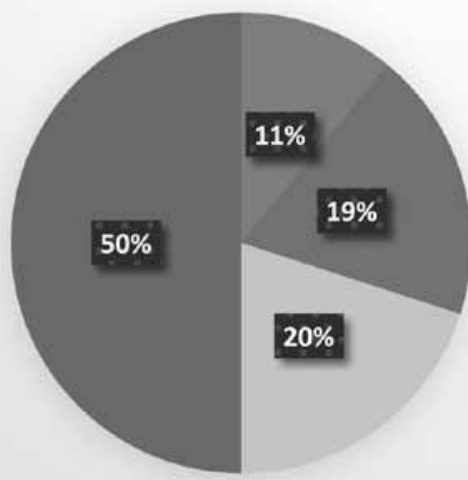

nealt care workers

- Patients

Iill I don't know, I don't have an opinion on that

noth

Chart $4^{16}$

\section{Do your colleagues, and how often are they themselves asking for something in return for the care or the tasks they provide?}

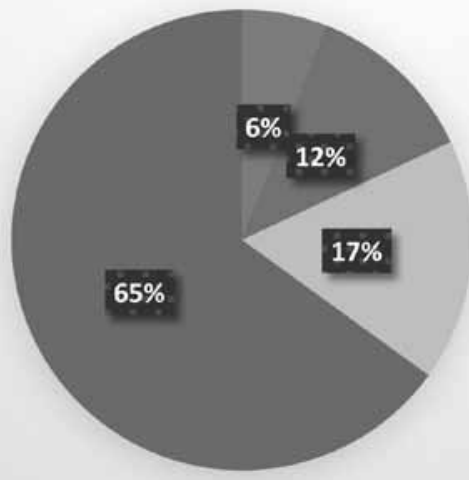

aften

- Ralely

inery rarely

never

15 Center for Free Election and Democracy (2010): Corruption in Health care.

16 Center for Free Election and Democracy (2010): Corruption in Health care. 


\section{Conclusion}

Being a health care worker has always been considered to be the most humane profession in the society. Based on numerous indicators, it can be concluded that medical profession in Serbia is for a number of health workers, an opportunity for acquiring material gain, violating basic human values, principles of humanity and above all the law. The consequences of such actions are not only reflected on causing damage to individuals, but also to the society as a whole. In the first place, system corruption in health care makes the path for Serbia into the EU more difficult. The accession of Serbia to the EU would solve the pressing economic problems and enhance the development of the whole society, including the health care system. Further on, it can be concluded that specific types of corruption in the health care system harm the budget of Serbia. Particular damage is reflected in the "takeover" of patients from state health institutions into the private ones. As a consequence, the money that could be used for the development of the health care system is spent for the development of private health care institutions whose owners are mainly corrupt doctors. Finally, poorer level of health care slows down the economic development of the society.

\section{Literature}

- Government of Republic of Serbia, Anti-Corruption Council, the official website

- Danilovic, N.: Contemporary security systems, Megatrend, Belgrade.

- Law on Health Care: "Official Gazette of RS", no. 107/05, 72/09- state law, 88/10, 99/10, 57 / 11,119 / 12, 45/13-state law, 93/14, 96/15 and 106/15.

- Ignjatovic, Dj. (2011): Criminology, Dosije studio, Belgrade.

- Code of Medical Ethics of the Medical Association of Serbia, "Official Gazette RS", nos. 104/2016.

- Center for Free Election and Democracy (2010): Corruption in Health care.

- Criminal Code, "Official Gazette of RS”, nos. 85/2005, 88/2005 - emendation, 107/2005 - emendation., 72/2009, 111/2009, 121/2012, 104/2013, 108/2014.

- National Anti-Corruption Strategy for period 2013-2018, "Official Gazette of $R S^{\prime \prime}$, nos. 57/2013.

- Republic of Serbia, High Court in Belgrade.

- Petrus C. van Duyne, Elena Stocco, Jelena Dimitrijević (2012): From black box to a transparent public policy, Victimology Society of Serbia, Belgrade. 


\section{KORUPCIJA KAO FAKTOR UGROŽAVANJA RAZVOJA ZDRAVSTVENOG SISTEMA U REPUBLICI SRBIJI}

Osnovni problem istraživanja u ovom radu je korupcija u zdravstvenom sistemu Republike Srbije, sa težištem na krivična dela protiv službene dužnosti, odnosno krivična dela iz člana 367. i 368. KZ Republike Srbije, primanje i davanje mita počinjena od strane zdravstvenih radnika. Predmet rada istražuje korupciju kao faktor ugrožavanja razvoja zdravstvenog sistema. Cilj rada je sticanje odgovarajućeg, naučnog i društvenog saznanja o pojavnim oblicima korupcije i mehanizmima koje državni organi treba da preduzmu u borbi protiv ovog oblika ugrožavanja društva u celini. Zdravstvena zaštita predstavlja organizovanu i sveobuhvatnu delatnost društva čiji je cilj postizanje najvišeg mogućeg nivoa očuvanja zdravlja gradana i porodice. Prema tome, veći nivo korupcije u zdravstvu, znači manji nivo zdravstvene zaštite u društvu. Odnosno, ukoliko je stepen zdravstvene zaštite lošiji, utoliko je ekonomski razvoj društva usporeniji. Posebno je važno istaći da je borba protiv korupcije u zdravstvenom sistemu jedan od uslova za pridruženje EU. Podaci u istraživanju su prikupljeni od strane udruženja pacijenata, pravosudnnh organa $i$ drugih organizacija.

Ključne reči: korupcija, zdravstveni sistem, ekonomski razvoj, primanje mita, davanje mita, pacijent. 